tissues does not imply also the redevelopment of the insect. That the tissues are all so redeveloped is undoubted, but they are not all redeveloped at once. I have stated in my book again and again that certain organs are redeveloped in a particular manner, and was never under the impression that the whole was a case of alternate generation. I did not know the origin of the imaginal discs in those days.

With your permission I will add a few words in support of the assertion "that the pupa change is analogous to ordinary ecdysis, of which it is a modification." In ordinary ecdysis the muscles undergo degeneration at their points of attachment to the cast skin; in metamorphosis this change is far more marked. In ecdysis in Chloëon, for instance, Sir J. Lubbock (Linn. Soc. Trans., vol. xxiv.) has shown that the wings and thorax are gradually developed through nine successive sheddings of the skin. In the more remarkable metamorphosis of Lepidoptera they are developed in two ecdyses, these two being called metamorphosis. Prof. Owen believed, and the assertion is now widely known, that the larvæ of such insects as the Orthoptera, Neuroptera, \&c., exist in the maggot form in the egg; but the observations of Mr. Newport on Meloe, and of Fritz Miiller, of Weismann, and many others, go far to prove that this is not so-that the maggot form is intermediate, the half-developed embryo and the pupa or perfect insect, being most alike.

The subject is one of great interest, and therefore I trust you will excuse this long trespass on your pages.

99, Guilford Street

BenJamin T. Lowne

\section{In $\operatorname{Re}$ Fungi}

Youn sarcastic correspondent "F. $\mathrm{Y}_{\text {. }} \mathrm{S}$." is quite incompetent to reply to my former letter. I did not call in question the correctness of the determination of Agaricus cartilaginews, but merely drew attention to the absurdity of the statement that the said determination was made from a mere " mass of mycelium, and that such a statement should come from a journal specially devoted to Botany.

In the original report of the occurrence of Ayarich cartila gincus (Foumal of Botany, vol. iii. p. 28) special reference is there made to the "many-headed pileus;" now some of these "pilei" (not the "mycelium," "F. L. S.,") were forwarded to the Rev. M. T. Berkeley for examination, and from these materials he (and not the writer of these lines) made out the plant to be $A$. cartilaginus. Certainly I included the species "without hesitation" in the list of Middlesex Fungi, because $Y$. knew the plant referred to had not been determined from a mere "mass of mycelium," but that Mr. Berkeley had examined the perfected parts.

I fail to see why "F. L. S." is so anxious to "allay my alarm as to the decay of Furgology in England," especially as I have never expressed any "alarm" on that head. I do not look upon the foumal as such an infallible weathercock as to connect its wiong statement with a national breakdown in Botany ; neither do I see how I have "missed the point" of its paragraph. I am more inclined to think that $I$ have hit it in a friendly way, and rather hard too.

W. G. S

\section{Mr. Baily on Kiltorkan Fossils}

In your last number Mr. Baily is said to have brought forward at a meeting of the Geological Society of Dublin "some strong facts to prove that the Irish palæontolugists had not misled Prof. Heer, as stated by Mr. Carruthers at a recent meeting of the London Geological Society."

At the meeting referred to, Prof. Heer placed the Irish beds at the base of the Carbonifrous series, mainly because Sagonaria Veltheimiana, a coal measure plant, was found in them.

Into this error I said "Prof. Heer had been led chiefly by the erroneous determination of the Kiltorkan Lepidodendron by the Irish palaeontologists." I will not burthen your columns with the strange history of the nomenclature of this plant, as I shall have an opportunity of doing this elsewhere ere long. The point before us is this, that $\mathrm{Mr}$. Baily alone has the credit of erroneously determining the Kiltorkan plant to be the same as an already described Carboniferous species. And the proof of this is easily adduced. In 1864, Mr. Baily, in his "Explanation of Sheets 187, \&c. , of the Irish Survey," figures the fossil, and describes it unhesitatingly as "Sagenaria Veltheimiana, Sternb. sp." This he repeated in a paper by the lamented Prof. Jukes in I866
(Fourn. Geol. Soc. Ireland, i. pp. 123, I24), as well as in a paper by himself read to the Natural History Society of Dublin in the same year (p. 2). Prof. Heer acknowledged his obligations to Mr. Baily for the Irish specimens he had examined. I have examined specimens so distributed by $\mathrm{Mr}$. Baily, and they were named Sagenaria Veltheimiana.

In the volume of the British Association Reports, published in r869, Mr. Baily says (p. 59) that the Sagenaria is named by Schimper $S$. Bailyana. More recently (Nov. I87 I), in his "Figures of British Fossils" (p. 84), he names it Knorric Bailyana. It is not much to the purpose to say that it is neither a Knorria nor a Sagenaria, or further that the specific designation Bailyana must give place, with some dozen other synonyms, to the original name given by Dr. Haughton in 1855 . But it is to the purpose to notice that Sugcnaria Veltheimiana is not a Kiltorkan fossil, though said to be so by Mr. Baily, and that this error, now acknowledged by Mr. Baily himself, was the main foundation of Prof. Heer's argument.

I am not a little curious to know what are the "strong facts" which will overthrow a plain narrative that fully justifies my statement, but at the same time compels me to make it more personal than the truth seemed to me to demand when $I$ made it some months ago. WILLIAM CARRUTHERS

\section{ZOOLOGJCAL RESULTS OF THE ECLIPSE

$$
\text { EXPEDITION }
$$

A STEAMER is eminently unqualified for observations $A$ on marine zoology. Owing to the high rate of speed, it is impossible to use a towing net with any success, and to a zoologist it is perfectly tantalising to see swarms of Medusae, \&c., sail past the ship without being able to obtain a single specimen. In Peninsular and Oriental ships the only practicable method is to keep the tap of the baths constantly running through a fine gauze net. In this way quantities of Entomostraca may be obtained. Since we have been in the Red Sea, the water has been splendidly phosphorescent every night, the light being most brilliant where the hot water from the condensers is shed out into the sea, the animals being pro. bably killed by the heat, and emitting in the act one last brilliant flash. If the water be turned on into one of the baths at night, most gorgeous flashes of light are obtained, and the animals causing them may be caught in small vessels and kept for examination. They are at present almost exclusively Entomostraca of the genera Cypris, Cyclops, and Daphnis. When the light is examined spectroscopically, it gives a spectrum in which only the green and yellow are present, the red and blue being sharply cut off. Several species of the Entomostraca obtained contain a brilliant red pigment, which gives unfortunately no absorption bands when examined with the micro-spectroscope. At Suez I obtained a number of Echinodermata of the usual dark purple tint, a splendid Comatula in abundance, two species of Echinus, and one or two star-fishes. The colouring matter of these animals is readily soluble in fresh water or alcohol, as is that of the common British feather-star. Though its colour is extremely intense, it gives no absorption bands, but when a strong solution is used, the spectrum is reduced to a red band, all the rest of the light being $a b$. sorbed. Apparently parasitic on a large fixt Spatangus, were obtained a number of $r \in d$ Planarians, about one-tighth inch long, which gave the characteristic absorption bands of hæmoglobin with great intensity. The existence of hæmoglobin in Planarians is a fact of considerable interest, and I believe quite new, On taking a boat excursion round the shores, where I obtained abundance of large Gasteropods and the Echinodermata mentioned above, I was remarkably struck by the absence of Actinias. Though I was out nearly the whole day, I did not see a single specimen, nor indeed did I observe any large Medusa. This absence of these latter may perhaps, however, have been due to the set of the wind or tide. 
Of the Suez Canal fauna we were able to observe very little, except that the canal perfectly swarms with fish from one end to the other. A good many were taken with hand-lines in two spots, one close to Port Sail, the other in the middle of the Great Bitter Lake. They were all of one species, a sort of mullet, but there are no books at hand to determine the species. The mud brought up from the bottom of the Great Bitter Lake by the chain cable was absolutely devoid of any traces of life. The Mirsapore has been visited on her voyage by various land birds. One hen chaffinch accompanied us from Cape Finisterre to Port Saïd, not leaving the ship when she was anchored at Malta, and was to be seen every day hopping about the deck and feeding. At present the ship is surrounded by vast flights of flying fish. They fly generally up wind, and sometimes go as far as one hundred yards.

It is hoped that this short note may be found of some interest, and that it will be borne in mind that it is impossible to travel about with a library sufficient to determine species on the spot.

\section{H. N. MOSELEY}

\section{MELTING AND REGELATION OF ICE}

$A^{N}$

$\mathrm{N}$ observation made yesterday caused me to present to my class, in a lecture on Heat this morning, the following experiment. A piece of wire gauze was laid on a convenient horizontal ring, and on this a lump of ice. A flat board was placed on the ice, and pressure was applied by means of weights put upon the board. I put 12 lbs. upon a piece of ice as large as an apple. This was done at the commencement of the lecture, and before the con. clusion I found a considerable quantity of ice on the lower side of the gauze, apparently squeezed throush the meshes. The temperature of the class-room was about $15^{\circ} \mathrm{C}$. $\left(59^{\circ} \mathrm{Fah}\right.$.). The experiment was continued for eight or ten hours, fresh ice being supplied when necessary to the upper side of the gauze, and, in spite of the continual surface melting and dripping away of water, a very large quantity of ice was formed below the gauze. The ice below the gauze was firmly united to that above. I tried with my hands to break away the upper from the lower, and to break either of them off at the place where the wire gauze separated them; but I was not able to do so. 'The ice that has passed through the meshes has a kind of texture corresponding to that of the network, and the small air bubbles appeared to be arranged in columns.

The phenomenon is a consequence of the properties, announced from theory by Prof. James Thomson, and then exemplified by an experiment ; and the explanation depends on the theories put forward by him-the first (1857) founded on the lowering of the frreezing point of water by pressure, and the second (186r) founded on the tendency to melt given by the application to the solid ice of forces whose nature is to produce change of form as distinguished from forces applied alike to the liquid and solid. The stress upon the ice, lue to its pressure on the network, gives it a tendency to melt at the point in contact with the wire, and the ice, in the form of water intermixed with fragments and new crystals, moves so as to relieve itself of pressure. As soon as any portion of the mass is thus relieved, freezing takes place throughout it, because its temperature is reduced below that of the freezing point of water at ordinary pressures, by melting of contiguous parts. The obvious tendency of the ice under the pressure from above is thus, by a series of meltings and refreezings, to force itself through the meshes.

The next experiment that I tried I was led to by that just described. I supported a block of ice on two parallel boards, placed near to each other, and passed a loop of wire over the ice. The loop hung down between the boards, and weights were attached to it. The first wire tried was a fine one $(0.007$ inches diameter) and a two-pound weight was hung on the loop. The wire immediately entered the ice, and it passed right through it and dropped down with the weight after having done so, but it left the ice undivided, and on trying it with a knife and chisel in the plane in which the cutting had taken place, I did not find that it was weaker there than elsewhere. The track of the wire was marked by opacity of the ice along the plane of passage. This opacity seemed to be due to the scattering of air from the small bubbles cut across by the wire. I have not, however, been able to try a piece of ice free from bubbles; and, from the nature of the experiment, air may very possibly pass in along the wire from the outside. I next experimented with a wire $0^{\circ} 024$ inches diameter, weight. ing the loop with $8 \mathrm{lbs}$, and obtained a similar result; and, finally, I took a wire $O$. I inch diameter, and, putting a 56lb. weight on a loop of it, I caused it to pass through the ice, and the block remained undivided. This, though it follows from theory, has a most startling effect ; and during the passage of the thick wire through the ice, I was able to see the bubbles of air across which it cut rising up round its sides. I made careful trials to cut the ice with a knife in the lamina through which the wire had passed, but found no weakness there.

A string was next tried, but, as might be expected, it did not pass through the ice. I considered that the string was not a good enough conductor to relieve itself of the cold in front and pass it back to the water behind. The capillary action of the string also doubtless takes part in the production of the result. It simply indented the ice and froze into it.

On this point of the necessity for a good conductor, and for a way of relieving itself of the cold, a curious observation was made. In one case a thick wire appeared to have stopped (this requires confirmation) as if it were frozen into the ice. On examination it turned out that the ice was so placed that the water formed by the pressure of the wire had flowed away at the first, and a hole was left behind the wire. On supplying a few drops of water to the place from a small pointed bit of melting ice, the water froze instantly on coming in contact with the wire, and the wire moved forward as usual. By this I was also led to try putting a thick wire over a piece of ice having a hollow at the top, so that the wire cutting into the shoulders bridged across the hollow between them. Looking at the wire, which was in front of a window, I dropped some ice-cold water on it, and saw it freeze instantly into crystals on the parts of the wire near to the shoulders on which it was pressing. This is notable as the first experimental confirmation of Prof. Thomson's theory on the production of cold by the application of stress.

I have not yet had an opportunity of trying these experiments at a temperature lower than freezing. The amount of pressure necessary to make the wire pass through the ice would of course be very much increased as the temperature is lowered, and it would finally be impossible to cut the ice without breaking it up like any other hard solid. Indeed I saw in one case in which I had a very great weight (8olb. or so) on a thick wire, the ice cracking in front of the wire; apparently the wire was forced too fast through the ice.

These experiments seem to me to have considerable importance in relation to the sliding motion of glaciers The smallness of the cause has been raised as an objection to the theory of Prof. Thomson. But no one can see the experiments I have described, particularly the first, where a large quantity of ice is squeezed through the meshes of fine wire gauze under small pressure and in a short time, without feeling almost surprised at the slowness of the glacier motion.

Glasgow University, Dec. 20, 187 I 